\title{
Paradoxical lack of increase in endothelin-1 levels in obese mice - possible role of endothelin-B receptors
}

\author{
Oliver BARETELLA ${ }^{1,2}$, Sookja K CHUNG ${ }^{2,3,4},{\text { Aimin } \mathrm{XU}^{1,2,4,5} \text {, Paul M VANHOUTTE }}^{1,2,4, \text { * }}$ \\ ${ }^{1}$ Department of Pharmacology \& Pharmacy, ${ }^{2}$ State Key Laboratory of Pharmaceutical Biotechnology, ${ }^{3}$ School of Biomedical Sciences, \\ ${ }^{4}$ Research Centre of Heart, Brain, Hormone \& Healthy Aging, and ${ }^{5}$ Department of Medicine, Li Ka Shing Faculty of Medicine, The \\ University of Hong Kong, Hong Kong SAR, China
}

Acta Pharmacologica Sinica (2017) 38: 1699-1700; doi: 10.1038/aps.2017.155; published online 9 Nov 2017

\section{Dear Editor,}

We have published in this journal a study investigating comprehensively the vascular responses in a mouse model of heterozygous endothelial overexpression of the endothelin-1 gene concluding that the latter in combination with obesity aggravates renal arterial dysfunction ${ }^{[1]}$. In the course of this study we performed additional measurements leading to intriguing observations that we would like to share with the readership of the journal.

Endothelin-1 contributes to increased vascular reactivity and tone under cardiovascular risk conditions including obesity in both humans and animal models ${ }^{[2]}$. However, plasma levels of the potent vasoconstrictor peptide in mice are increased significantly only after eg three weeks of high fat feeding ${ }^{[3]}$ but no longer following ten weeks ${ }^{[4]}$, and they are the same as in lean animals on standard chow after thirty weeks of dietinduced obesity ${ }^{[1]}$. In addition to plasma endothelin-1 levels, pulmonary tissue contents have been determined in mice fed standard chow or high fat diet during such prolonged time using an ELISA kit ${ }^{[1]}$ following tissue extraction as described ${ }^{[5]}$. Across the organs, the lungs contain the highest levels of the peptide $^{[5]}$, and were used to compare endothelin- 1 contents between lean and obese animals. By contrast to the similarly low plasma peptide levels in lean and obese wild type mice and littermates with heterozygous endothelial over-expression of the prepro-endothelin-1 gene $\left(\mathrm{TET}^{\text {het }}\right)^{[1]}$ on standard chow or high fat diet, endothelin-1 levels in the lungs were significantly higher (Figure 1A). Surprisingly however, these tissue levels were lower in the lungs of obese than in those of lean animals (Figure 1A) having similar endothelin-1 contents in the lungs as reported ${ }^{[5]}$.

\footnotetext{
${ }^{*}$ To whom correspondence should be addressed.

E-mail vanhoutt@hku.hk

Received 2017-05-18 Accepted 2017-10-26
}

Endothelin-1 acts via two distinct receptor subtypes [endothelin- $\mathrm{A}\left(\mathrm{ET}_{\mathrm{A}}\right)$ and endothelin- $\left.\mathrm{B}\left(\mathrm{ET}_{\mathrm{B}}\right)\right]$ mediating the characteristic vasoconstrictor response upon activation by the peptide of vascular smooth muscle cells ${ }^{[2]}$. By contrast, activation of endothelial $\mathrm{ET}_{\mathrm{B}}$-receptors promotes the generation of nitric oxide, which thus leads to inhibition of contraction and facilitated relaxation ${ }^{[2]}$. Furthermore, $\mathrm{ET}_{\mathrm{B}}$-receptors in the lungs are responsible for the clearance of the peptide especially in rodents ${ }^{[6]}$, where endothelial $\mathrm{ET}_{\mathrm{B}}$-receptors play a crucial role in this process ${ }^{[7]}$. This may help to explain, at least in part, why plasma endothelin-1 is not increased by obesity in mice ${ }^{[1]}$.

As in humans, murine obesity is accompanied by augmented plasma cholesterol levels ${ }^{[8]}$, which was also evident from our data (Figure 1B). Low-density lipoproteins augment both the gene expression and the protein presence of $\mathrm{ET}_{\mathrm{B}}$-receptors in endothelial cells ${ }^{[9]}$, and the gene expression of both the $\mathrm{ET}_{\mathrm{A}}$ and $\mathrm{ET}_{\mathrm{B}}$-receptors is increased in tissue of obese compared to lean mice ${ }^{[4]}$. In these respects, we found increased $\mathrm{ET}_{\mathrm{B}}$-receptor protein presence in the lungs of obese compared to lean animals (Figure 1C) using established antibodies ${ }^{[4]}$. Such an up-regulation of the $\mathrm{ET}_{\mathrm{B}}$-receptor pathway in the lungs, a tissue of high endothelial cell content, would support the decreased pulmonary tissue endothelin-1 levels observed in obese mice as a likely consequence of an accelerated clearance ${ }^{[6]}$. This may occur despite an augmented $\mathrm{ET}_{\mathrm{B}^{-}}$ receptor mediated increase in vascular tone as seen in some peripheral arteries from obese animals, in particular in those of endothelin-1 gene overexpressing mice ${ }^{[1]}$ and contribute to the less than expected vascular and metabolic phenotype. As regards the latter aspect, this may prevent them (or longterm high fat fed wild-type mice in general) from exhibiting elevated circulating endothelin-1 levels as in obese humans ${ }^{[10]}$ despite the present hyperinsulinemia ${ }^{[1]}$. Moreover, in obese mice, arterial blood pressure could remain in the normotensive range $^{[1]}$ due to an accelerated clearance of the peptide despite 

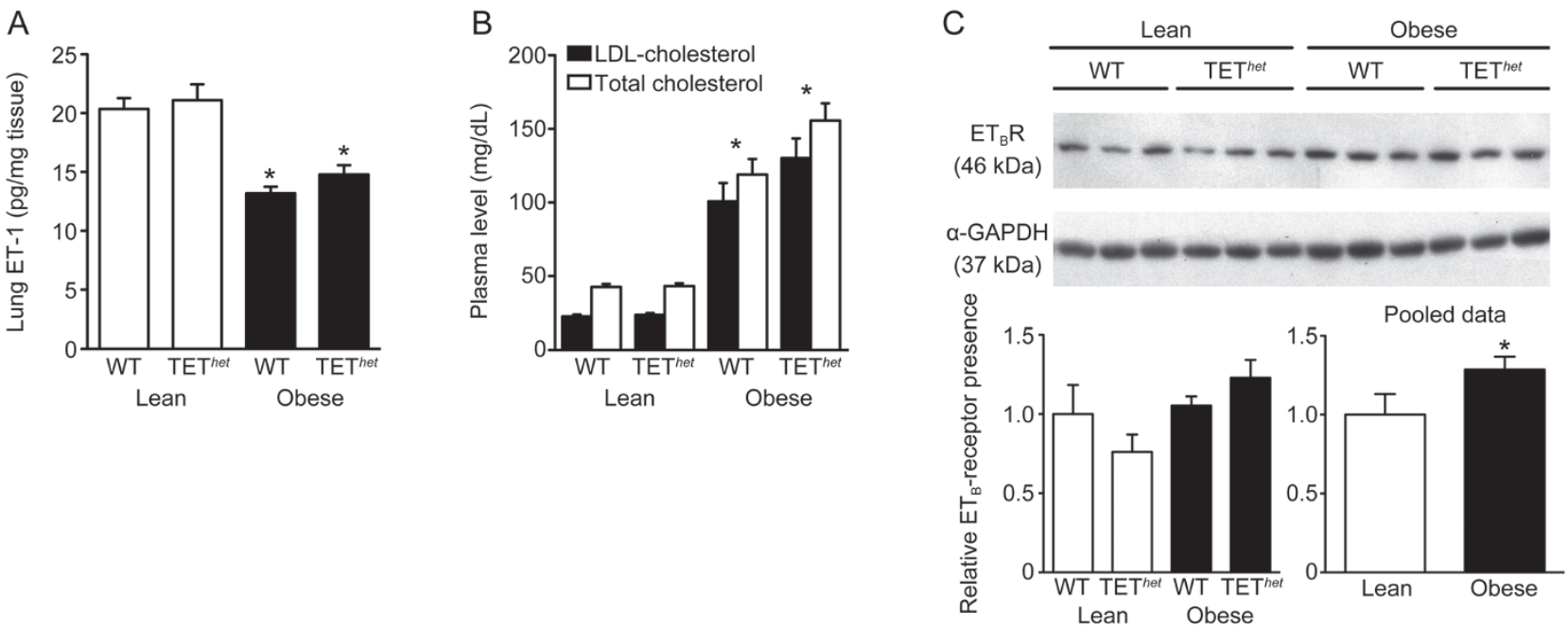

Figure 1. Endothelin-1 (ET-1) content in lungs [ $n=5-12$, as picograms per milligram (pg/mg) lung tissue] (A) of wild-type (WT) mice and littermates with heterozygous endothelial overexpression of the endothelin-1 gene ( $\mathrm{TET}^{\text {het }}$ ) on standard chow (lean) and after 30 weeks of high fat feeding (obese). Lowdensity lipoprotein (LDL)- and total cholesterol contents were determined in plasma (B). Finally, endothelin-B ( $\left.\mathrm{ET}_{\mathrm{B}}\right)$-receptor presence was measured in lungs by Western blotting, expressed relatively to alpha-glyceraldehyde-3-phosphate dehydrogenase ( $\alpha$-GAPDH) content and samples of lean and obese animals $(n=7)$ compared $(C)$. The data are shown as mean \pm SEM. ${ }^{*} P<0.05$ versus lean controls.

an increased renal tissue content ${ }^{[8]}$.

Taken in conjunction, our results suggest that the activity of $\mathrm{ET}_{\mathrm{B}}$-receptors may not only be increased in arteries of obese, especially endothelin-1 gene overexpressing mice ${ }^{[1]}$, but also in lung tissue of these animals with diet-induced obesity leading to an augmented clearance of the peptide. Mechanistically this can be explained by the hypercholesterolemia linked to this diet-induced obesity model causing an up-regulation of $\mathrm{ET}_{\mathrm{B}}$-receptors in endothelial cells ${ }^{[9]}$. Hence, the potent vasoconstrictor peptide endothelin-1 may be cleared more effectively by these receptors ${ }^{[6]}$ on pulmonary endothelial cells ${ }^{[7]}$ in obese compared to lean animals making the phenotype in the overexpression model less dramatic than expected under the cardiovascular risk condition of obesity.

\section{Acknowledgements}

This work was supported by the Swiss National Science Foundation (grants 138754 and 143672 to Oliver BARETELLA), and the Hong Kong Research Grant Council (780410M). The authors thank Boris CHAN for help with blinded assays of endothelin-1; Pan YONG and Dr Dewei YE for advice with Western blot techniques.

\section{Author contribution}

All authors designed research by helping to develop the experimental design; Oliver BARETELLA performed all of the experiments, analyzed the data and wrote the manuscript; Sookja K CHUNG contributed transgenic animals; Paul M VANHOUTTE edited the manuscript and all authors reviewed and approved the manuscript.

\section{References}

1 Baretella O, Chung SK, Xu A, Vanhoutte PM. Endothelial overexpression of endothelin-1 modulates aortic, carotid, iliac and renal arterial responses in obese mice. Acta Pharmacol Sin 2017; 38: 498-512.

2 Baretella 0, Vanhoutte PM. Endothelium-dependent contractions: prostacyclin and endothelin-1, partners in crime? Adv Pharmacol 2016; 77: 177-208.

3 Adiarto S, Emoto N, Iwasa N, Yokoyama M. Obesity-induced upregulation of myocardial endothelin-1 expression is mediated by leptin. Biochem Biophys Res Commun 2007; 353: 623-7.

4 Catar RA, Muller G, Brandt A, Langbein H, Brunssen C, Goettsch C, et al. Increased gene expression of the cardiac endothelin system in obese mice. Horm Metab Res 2015; 47: 509-15.

5 Kisanuki YY, Emoto N, Ohuchi T, Widyantoro B, Yagi K, Nakayama K, et al. Low blood pressure in endothelial cell-specific endothelin 1 knockout mice. Hypertension 2010; 56: 121-8.

6 Fukuroda T, Fujikawa T, Ozaki S, Ishikawa K, Yano M, Nishikibe M. Clearance of circulating endothelin-1 by $\mathrm{ET}_{\mathrm{B}}$ receptors in rats. Biochem Biophys Res Commun 1994; 199: 1461-5.

7 Kelland NF, Kuc RE, McLean DL, Azfer A, Bagnall AJ, Gray GA, et al. Endothelial cell-specific ETB receptor knockout: autoradiographic and histological characterisation and crucial role in the clearance of endothelin-1. Can J Physiol Pharmacol 2010; 88: 644-51.

8 Barton M, Carmona R, Morawietz H, d'Uscio LV, Goettsch W, Hillen $\mathrm{H}$, et al. Obesity is associated with tissue-specific activation of renal angiotensin-converting enzyme in vivo: evidence for a regulatory role of endothelin. Hypertension 2000; 35: 329-36.

9 Muller G, Catar RA, Niemann B, Barton M, Knels L, Wendel M, et al. Upregulation of endothelin receptor $B$ in human endothelial cells by low-density lipoproteins. Exp Biol Med (Maywood) 2006; 231: 76671.

10 Ferri C, Pittoni V, Piccoli A, Laurenti O, Cassone MR, Bellini C, et al. Insulin stimulates endothelin-1 secretion from human endothelial cells and modulates its circulating levels in vivo. J Clin Endocrinol Metab 1995; 80: 829-35. 